\title{
Development of SSR markers and genetic diversity evaluation of Mycocentrospora acerina causing round spot of Panax notoginseng in Yunan province, China
}

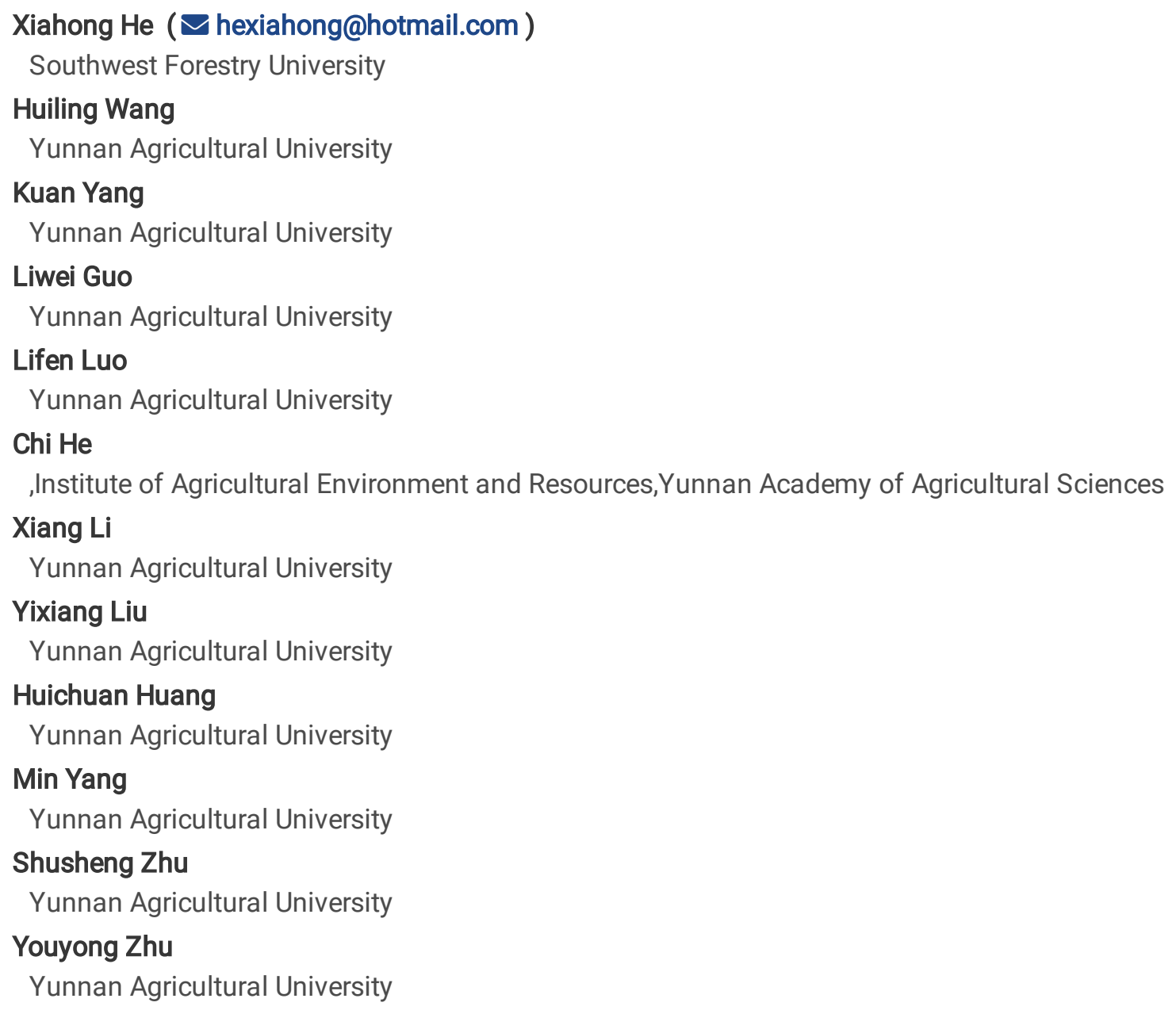

\section{Research Article}

Keywords: Panax notoginseng, Mycocentrospora acerina, SSR primers, genetic diversity

Posted Date: March 8th, 2022

DOI: https://doi.org/10.21203/rs.3.rs-1204134/v2

License: (a) (1) This work is licensed under a Creative Commons Attribution 4.0 International License. Read Full License 


\section{Abstract}

Background: Sanqi round spot, which is caused by Mycocentrospora acerina, is a destructive disease limits the production of Panax notoginseng in Yunnan province of China. However, the disease has not been studied comprehensively.

Results: In the current study, we identify M. acerina polymorphic microsatellite markers using CERVUS 3.0 and compare the genetic diversity of its isolates from $P$. notoginseng round spot using Simple Sequence Repeat (SSR) markers and polyacrylamide gel electrophoresis. Thirty-two SSR markers with good polymorphism were developed using MISA and CERVUS 3.0. The genetic diversity of 187 M. acerina isolates were evaluated using 14 representative SSR primers, and the polymorphic information content values of 14 sites ranged from 0.813 to 0.946 , with a total of 264 alleles detected at 14 microsatellite loci. The average expected heterozygosity was 0.8967 .

Conclusion: 14 SSR primers of M.acerina can be used in diversity analysis and identification of $M$. acerina and its closely related species. Genetic diversity of M. acerina in Yunnan province does not reflect geographic specificity.

\section{Background}

Sanqi [Panax notoginseng (Burk.) F. H. Chen], a member of the Araliaceae family, is mainly distributed in Yunnan Province, China. P. notoginseng is a valuable traditional Chinese medical herb with multiple pharmacological applications [1].

Ginsenosides and amino acids have various positive effects on the circulatory system, cardiocerebral vascular system, central nervous system, and endocrine system, and reduces inflammation [2, 3].

P. notoginseng is a perennial herb with more than 400-year cultivation history, with increasing demand in recent years, its cultivation area has increased rapidly [4]. However, large scale cultivation has led to the emergence of severe diseases in production, such as root rot, which is caused by Cylindrocarpon destructans var. Crassum [5], Fusarium oxysporum [6] and $F$. solani [7], round spot caused by Mycocentrospora acerina [8], and dark speckle caused by Alternaria panax [9]. Such severe diseases have limited the cultivation and production of Sanqi in Yunnan [10]. Round spot is the most severe disease affecting the leaves, and it spreads extremely rapidly in rainy season, causing $20-50 \%$ yield losses [11].

Round spot mainly occurs on the leaves, and develops further into a brown spot with a transparent point in the middle, finally forms gray-white mold layer and produces conidia of $M$. acerina [12]. The disease is caused by Ascomycotina, Dothideomyceta, Mycosphaerellaceae, Mycocentrospora, Mycocentrospora acerina (Hartig) Deighton [13], which is a quarantine pest in China. There are 23 species of fungi belonging to the Mycocentrospora genus. ( http://www.speciesfungorm.org/ ), all of which are plant pathogenic fungi. Moreover, $M$. acerina infects more than 20 plant species globally, including several economically valuable crops such as Daucus carota L. var. sativa Hoffm [14] and Paeonia lactiflora [15], and Acer L [16]. It is worth noting that $M$. acerina can infect nearly 23 kinds of weeds, mainly including blue pansy, scorpion, chamomile, bidens [17]. Although several reports have explored M. acerina disease prevalence and its biological characteristics [12], only a few studies have investigated its molecular biology.

M. acerina was firsted reported to cause leaf blight of Asarum in Liaoning Province in 1990 [18]. The fungus was reported to infect $P$. notoginseng in Yunnan Province of China in 1997 [19]. So far, $M$. acerina has been found to infect Asarum and $P$. notoginseng in China, and the impact on $P$. notoginseng is more serious. P. notoginseng is a unique Chinese herbal medicine, which can be cultivated only in Yunnan and Guangxi provinces of China. P. notoginseng round spot is the main leaf disease of $P$. notoginseng. If the control is not timely, the incidence rate of $P$. notoginseng round spot can reach $100 \%$, causing serious economic losses, especially in the rainy season, it often causes large-scale epidemic and transmission. In the field, the disease was mainly transmitted by the conidia on the leaves of $P$. notoginseng through rain splashing.

In the early 1820 s, plant pathologists began to pay attention to the relationship between changes in the genetic structure of pathogen populations and plant diseases. The pathogen population defined by geneticists early is a collection of individuals of the same species, including all genotypes in the population. The genotype is affected by the growth and extinction of the host, gene drift, environment, and reproductive methods. Therefore, the absolute pathogen population is difficult to define. Therefore, 
in actual research, the sum of the sampling of pathogen populations in a limited time and a certain space is usually analyzed as a population [20]. The genetic structure of plant pathogen population reflects the evolutionary potential and evolutionary history of pathogen [21]. Therefore, the ultimate goal of studying pathogen population genetics is to determine the factors that play a major role in the population evolution of pathogenic fungi, and to grasp the rules of interaction of these evolutionary factors.

In the history of agricultural production practice progress, plant pathogens have important economic and social impacts on humans, and the knowledge of the genetic diversity of plant pathogens will help people understand and control the agricultural ecosystem. The pathogenic fungus population is changing and will adapt to changes in the control methods and its living environment. Eventually, the genetic structure of the pathogen population changes, causing plants to lose resistance [22]. The speed of strain evolution is mainly reflected by the number of genetic variation in the pathogen population. This result will help the judgment of the effective maintenance time of disease prevention measures in agriculture. And pathogen populations with complex genetic structure can often adapt faster to the host's disease resistance or the sensitivity of fungicides. Therefore, the understanding of the genetic structure variation and distribution of phytopathogenic fungi populations will have important guiding significance for disease resistance breeding, the rational distribution of disease resistance genes, and the rational use of fungicides in production. The rapid development of molecular biology based on DNA carrying genetic information has made it a reality to accurately detect the genetic variation of plant pathogen populations [23].

Simple sequence repeat (SSR) is the simplest among numerous molecular marker methods used to evaluate levels of diversity in species. With the publication of genomic databases, SSR is convenient in the study of genetic diversity $[24,25,26]$. Pathogenic fungal populations exhibit variations across different locations as adaptations to changes triggered by control methods and diversity in their living environments [27]. The genetic structure of a pathogenic fungus population can also change and lead to loss of resistance in host plants [28]. Development of molecular markers for $M$. aceria could offer a more comprehensive genetic basis for $M$. acerina studies, which would enhance efforts to control Sanqi round spot. Therefore, understanding the variation in genetic structure and distribution of plant pathogenic fungi populations could enhance our understanding of the distribution of genetic informatin and facilitate the formulation of appropriate disease control strategies $[29,30]$.

In this study, we analyzed the SSR characteristics in the M. acerina genome and developed SSR primers from M. acerina. Moreover, the effectiveness of the primers in analyzing population genetic diversity structure in $M$. acerina was analyzed.

\section{Results}

\section{Isolation and identification of strains}

All the isolates were identified based on their colonies and conidium (Figure 1A, B), and symptoms on inoculated plants were similar to those of plants growing in the field (Figure 2C, D). Phylogenetic trees, constructed based on internal transcribed spacer (ITS1/4) sequences, showed that the isolates were grouped with M. acerina (Figure 3).

\section{Genomic SSR analysis}

A total of 8250 microsatellite sequences with 1 to 6 base repeats were obtained from the M. acerina genome. The average length of SSRs was $26 \mathrm{bp}$. SSR lengths of different repeat types were varied.

Among the SSRs, there were 3379 mono-nucleotide repeats, which accounted for $40.96 \%$ of the total repeats. Among the mononucleotide repeats, 113 repeats were repeated more than 30 times. In addition, there were 2137 tri-nucleotide SSRs (25.90\%) and 179 penta-nucleotide repeats, which accounted for the lowest proportion (2.17\%), with hexa-nucleotide repeats accounting for $3.71 \%$ of the total repeats. The maximum repetition times of each of the SSRs were 81, 40, 155, 217, 72, and 144 (Figure 4). Such SSRs with abundant repeats are beneficial to the development of molecular markers. 
Based on the proportions of mono-nucleotide SSRs of M. acerina, T or A bases existed in single nucleotide SSR, and the number of poly $T$ or $A$ bases was 2449 , accounting for $72.47 \%$ of the bases. There were 930 repeats with $C$ or $\mathrm{G}$ bases, which was far less than those with T or A bases. Among the di-nucleotide repeats, there were four types of SSR sequences: AC, AG, AT, and CG. AG/CT repeats accounted for $49.84 \%$ of all the di-nucleotide repeats, followed by AC/GT and AT/AT. CG/CG type repeats were the least (9\%). Among the tri-nucleotide repeats, AAC/GTT, AAG/CTT, and AAT/ATT were the main types. Overall, AAG repeats were the most abundant, accounting for 22.28\%, and CCG content was the least (3.89\%) (Figure 5).

The numbers and proportions of tetra-, penta-, and hexa-nucleotide repeats in the $M$. acerina genome are listed in supplementary table 1, 2, and 3 . There were 28 types of tetra-nucleotide repeats, among which ATCC had the highest content $(12.48 \%)$, and CCCG had the lowest content $(0.16 \%)$. In addition, there were 61 penta-nucleotide repeats, AACAC and AATCC accounting for the largest proportions. Hexa-nucleotide repeats were the most abundant (103), AACCCT was the most common, with 44 motifs.

\section{Polymorphism of SSR Primers}

Thirty-two pairs of primers had highly polymorphic loci ([PIC] $>0.5$ ) and could be used as SSR markers in the construction of an M. acerina genetic map and for genetic diversity analyses. PIC is commonly used to assess the degree of gene variation. A locus can be considered a highly polymorphic marker when its PIC value exceeds 0.5 . According to the SSR primer data (Table 2 ), the average PIC was 0.6492 , the average allele number per locus was 5.147 , the average proportion of locus types was 1.00 , and the average expected heterozygosis $(\mathrm{He})$ was 0.7212 .

\section{Genetic diversity within populations}

A total of 148 polymorphic bands were amplified from 187 populations of $M$. acerina using 14 SSR primers. The PIC of 14 loci ranged from 0.813 (MP56) to 0.946 (MP114), with an average PIC value of 0.8852 , all of which were highly polymorphic. A total of 264 alleles were detected at 14 microsatellite loci, out of which 14 alleles were detected on MP61 with the least number. Thirty-one alleles with high diversity were detected on MP114. The average number of alleles per locus was 18.857 . The observed heterozygosis $(\mathrm{Ho})$ of 14 loci was 0 , and He ranged from 0.831 to 0.951 , with an average of 0.8967 .

\section{Diversity between populations}

Nei's genetic diversity (0.0896) and Shannon's information index (0.1712) were the highest in the Honghe population $(\mathrm{HH})$, followed by in the Puer population (LC); and the lowest in Lijiang, at 0.0842 and 0.143 , respectively (Table 3 ). The genetic diversity in different populations was relatively low.

The average observed allele number $(\mathrm{Na})$ was 2.00; the average effective allele number was 1.11; the Nei' gene diversity $(h)$ was 0.0908; and the average Shannon diversity index was 0.1761. In addition, the total genetic diversity (Ht) was 0.0909; the intrapopulation genetic diversity (Hs) was 0.0884 , and the genetic differentiation index (Gst) was 0.0277 , which indicates that there was very low genetic variation of $2.77 \%$ variation among populations. The estimated level of gene flow (Nm) was 17.5757, which indicates that there were numerous changes to genes attributed to gene flow in different regions, and that gene flow was not the primary factor influencing genetic diversity in the population.

Among the six populations, the populations from Kunming and Honghe had the greatest genetic similarity (0.9988) and the least genetic distance (0.0012). In addition, Lijiang and Lancang had the least genetic similarity (0.9931) and the largest genetic distance (0.007) (Table 4). Generally, the genetic distances between the populations above were small, and their genetic similarity coefficients were close to 1 , which indicated that the genetic relationships between strains in each population were close, and there was low genetic differentiation among different populations. 


\section{Cluster analysis}

Cluster analysis revealed that the maximum similarity coefficient was 0.97 and the minimum was 0.83 among $187 \mathrm{M}$. acerina strains collected from 12 counties of 6 prefectures (cities) in Yunnan Province (Figure 6).

\section{Discussion}

\section{The biology of M. acerina and round spot of P. notoginseng in Yunnan}

In the 20th century, there were many studies on M. acerina, mainly focusing on the host diversity and transmission methods [13, 17, 31]. In the 21st century, few studies on $M$. acerina. Sébastien Louarn studied the influence of $M$. acerina on the polyacetylenes and 6-methoxymellein in organic and conventionally cultivated carrots (Daucus carota) during storage [32]. Since it was discovered in 1997 that M. acerina can infect the important economic crop of Chinese medicinal material $P$. notoginseng in Yunnan Province, our laboratory (Key Laboratory of Agricultural Biodiversity and Pest Control of the Ministry of Education) has examined the biological characteristics of $M$. acerina and a lot of research has been done on the trait of spread in the field, and it is found that $M$. acerina is a kind of low temperature-loving fungus. When the temperature exceeds $32^{\circ} \mathrm{C}$, its conidia will lyse, and the optimum growth temperature is $14-22^{\circ} \mathrm{C}$. The latest measured length of $M$. acerina is (137.36 $486.24 \mu \mathrm{m}) \times(4.35 \sim 16.46 \mu \mathrm{m})(\mathrm{n}=100)$, and a single conidia can cause infection (Supplementary Figs. 1 and 2). M. acerina cause initial infection through chlamydospores stored in the soil, and spread in the field through conidia on the leaf surface of infected leaves, causing re-infection. Conidia are mainly spread by rain splash. $P$. notoginseng has a serious problem of continuous cropping, it will take at least 10 years to replant. Therefore, it was only planted in Wenshan in the 1990s, and it has now spread to Kunming, Honghe, Lijiang and Jianshui. No matter where the $P$. notoginseng plants, $P$. notoginseng round spot disease will follow. It is not known whether it is because the $M$. acerina originally existed in the local area or the pathogen spreads with various media. The results of this study indicate that the genetic distances between the $M$. acerina populations in different regions are relatively close, and the similarity is high, which may indicate that there are frequent exchange activities between $M$. acerina in different regions, such as seedlings. Cross-regional transportation and other media dissemination. In addition, the prevention and treatment of $P$. notoginseng round spot is mainly concentrated in the rainy season (June to September). Using the technology of facility cultivation to build a rain-proof film in the rainy season can prevent $P$. notoginseng round spot and reduce the use of chemical pesticides(Supplementary Fig. 3). The reduction in the amount of chemical pesticides can reduce the survival pressure of $M$. acerina, which can also affect the genetic relationship between populations in different regions.

\section{Features of SSR loci in M. acerina}

A total of 8250 repeats were obtained from the screened SSR sequences, which indicated that the number of SSRs was high in the $M$. acerina genome compared to in some eukaryotes [33,34]. The analysis of microsatellite sequences in $M$. acerina could enhance our understanding of its genome structure, especially the composition of non-coding regions, and the mechanisms of pathogenicity and its heredity in M. acerina at the genome level. Among all SSR types, A and T are abundant, which is consistent with the SSR loci results in most eukaryotic genomes, probably due to the transformation of methylated $\mathrm{C}$ residues into T residues [35]. According to Velascor [36], the presence of a large number of short repeat sequences indicates that a species has a high mutation frequency, while species with high proportions of long repeat motifs generally have relatively short evolutionary times or low mutation frequencies [36]. A large number of short repeats of single, dibasic, and tribasic bases were observed in the genome of $M$. acerina, suggesting that $M$. acerina had a relatively high mutation frequency or a relatively short evolutionary time [37].

With advancements in genome sequencing technologies, molecular marker studies have become more cost-effective [38]. Based on genomic data, we obtained 8250 SSRs, which accounted for $0.55 \%$ of the whole genome sequences. In the Fusarium graminearum genome, SSR sequences obtained accounted for $0.27 \%$ of the whole-genome sequences [39] and $0.21 \%$ in the Sphacelotheca reilianm genome [40]. In this study, more than 100 pairs of primers were designed, out of which merely 32 pairs 
were polymorphic, probably because most of the selected primers existed in the coding regions of the genome, with only a few located in the non-coding regions. Studies have demonstrated that SSRs in coding regions often exhibit low polymorphism, and SSR markers should be designed as much as possible within non-coding regions, because coding regions have much greater selection pressure than non-coding regions and are relatively conserved in the course of species evolution, while non-coding regions are more likely to evolve or mutate $[41,42]$.

\section{Genetic diversity of M. acerina in Yunnan}

In the current study, the PIC of polymorphic loci ranged from 0.53 to 0.8 , which was high when compared to the PIC in other eukaryotes. For example, PIC ranged from 0.3 to 0.4 in Dactylis glomerata L. [43], 0 to 0.756 in Magnaporthe oryzae [44], and 0.305 to 0.726 in Panonychus citri [45]. According to the results based on primer polymorphism, 14 SSR loci were used to analyze the genetic diversity of $M$. acerina populations. the PIC of screened primers was higher; however, after population analysis, the genrtic diversity of $M$. acerina does not reflect geographic specificity. The potential reason is that the SSR primer loci are within the coding regions of the genome, which have high degrees of conservation [46]. Judicious selection of primers could improve the accuracy of results. The genetic diversities of Pyricularia oryzae Cav. and Puccina striiformis $\mathrm{f}$. $\mathrm{sp}$. tritici in Yunnan Province have been reported to be high $[47,48]$. Therefore, the genetic diversity obtained for $M$. acerina in the study could be due to the single genetic background of $M$. acerina as a quarantine pest in China [49] or its stable survival in areas with highly homogenous ecological environments for prolonged periods.

The automatic nucleic acid protein analyzer used in study is a novel instrument that can be applied in population genetics analyses. Compared with polyacrylamide gel electrophoresis, its operation is relatively simple and time saving, and it can simulate the electrophoretogram and directly read bands, which facilitates analysis procedures. In addition, it can be used directly for DNA and protein sample analysis $[50,51]$.

Some of the primary factors influencing the evolution of the population genetic structures of pathogenic fungi include population size, reproductive mode, and genetic drift [52, 53]. In this study, $189 \mathrm{M}$. acerina strains were selected, and the population number was moderate. The mode of reproduction of $M$. acerina in the field is asexual reproduction [54], which, to a certain extent, is not conducive to its genetic variation and the evolution of its populations. Pathogenic fungi are small individuals and easily experience genetic drift by natural or artificial means, and gene drift is generally considered to hinder the evolution of organisms [55].

In the current study, there were no significant correlations in genetic diversity among strains from different geographical sources. Continuous selection and mutation of pathogenic genes will lead to homozygous individual genes, thus reducing the genetic diversity level of $M$. acerina population. These factors can partly explain that the isolates from the same region cannot be totally clustered into a group, and some isolates from different regions have very high genetic similarity coefficient. Another possible explanation is that the host $P$. notoginseng is merely grown in Yunnan and Guangxi, China, and Wenshan in Yunnan is the place of origin. The rest of the sampling points in the paper have been gradually planting $P$. notoginseng in the past 5-6 years. Current research show that due to the low genetic diversity of maple populations, we can effectively prevent the occurrence of diseases in this area through timely cleaning of diseased leaves, rain-proof cultivation, and alternate use of chemicals [56].

\section{Conclusions}

In this study, we developed 14 SSR primers of M.acerina can be used in diversity analysis and identification of $M$. acerina and its closely related species. Genetic diversity of $M$. acerina in Yunnan province does not reflect geographic specificity.

\section{Methods}

\section{Strain isolation and observation}


M. acerina strains were collected from six major $P$. notoginseng production regions, including Honghe, Wenshan, Qujing, Kunming, Lijiang, and Puer in Yunnan Province (Table 1). The geographical distribution of the samples shown in Figure 8. M. acerina were obtained using tissue isolation [57]. The junction between healthy and diseased tissue was washed using sterilized water and then immersed in alcohol (75\%) for 2-3 min and washed again using sterilized water and dried on sterilized filter paper. Afterward, the samples were transferred into PDA medium and cultivated at $20^{\circ} \mathrm{C}$ for $4 \mathrm{~d}$. Then, we verified the isolates based on Koch postulates and pured by hyphal-tipped. M. acerina was identified based morphological characteristic and ITS sequence.

\section{DNA extraction and polymerase chain reaction amplification of internal transcribed spacer (ITS1/4) regions}

Genomic DNA was extracted from $0.2 \mathrm{~g}$ of mycelium using the Omega Fungi DNA Kit (Kunming Shuoqing Biological Engineering Technology Co. Ltd., Kunming, China) according to the manufacturer's instructions. Amplification reactions were performed in a $20 \mu \mathrm{L}$ volume containing $1 \mu \mathrm{L}$ template DNA, $10 \mu \mathrm{L}$ mix (DNA polymerase, Buffer, dNTP), $1 \mu \mathrm{L}$ primer ITS1

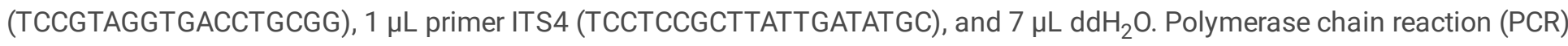
was performed using a T1 thermocycler (Biometra, Germany), with initial denaturation at $94^{\circ} \mathrm{C}$ for 5 min, followed by 35 cycles of $94^{\circ} \mathrm{C}$ for $45 \mathrm{sec}, 60^{\circ} \mathrm{C}$ for $45 \mathrm{sec}$, and $72^{\circ} \mathrm{C}$ for $90 \mathrm{sec}$, and a final extension at $72^{\circ} \mathrm{C}$ for $10 \mathrm{~min}$. Amplification products were separated by electrophoresis on $1 \%$ agarose gels in a $0.5 \times$ TAE buffer, using a 2000-bp DNA ladder as a DNA molecular weight marker. The PCR products were sequenced at Kunming Shuoqing Biological Engineering Technology Co. Ltd. Molecular Evolutionary Genetics Analysis (MEGA 5.1) was used to construct a phylogenetic tree based on the neighbor-joining method. Bootstrap values were evaluated using 1,000 replications [58].

\section{Simple sequence repeat screening}

SSRs were screened using MISA (http://pgrc.ipk-gatersleben.de/misa/) based on the whole genome data of M. acerina [59, 60]. MISA is a script written in Perl language, which can identify SSRs from genome FASTA files [61], MISA is simple to run without networking, and does not require high hardware. It has become the tool of choice for most SSR researchers. In the SSR parameter settings, we defined that six, five, four, three, two, and one base were repeated five, five, five, five, six, and ten times.

The genome (Accession: PRJNA809504) used in this study was sequenced using Hiseq 2500 from Illumina. After sequencing, two sets of $101 \mathrm{bp}$ long and short paired-end short sequence data were generated. M.acerina produced a total of $20.502 \mathrm{~Gb}$ original sequence, after filtering quality control, remove the linker sequence, low-quality base sequence and low sequence complexity sequence. The K-mer parameter is 75 , and the final assembly result is obtained after automatic assembly and gap filling using SOAP denovo software (BGI, Shenzhen, China). The assembled size of $M$. acerina is $39 \mathrm{Mb}$ in total. The N50 index is an evaluation index for the continuity of genome assembly, this value is calculated by sorting the contig sequence length from largest to smallest. The larger the N50 value, the better the continuity of the contig generated by the assembly. In this study, M. acerina genome assembly contig N50 is $151 \mathrm{~kb}$, scaffold N50 is $567 \mathrm{~kb}$, the assembly quality is credible.

\section{Primer design}

SSR primers for the whole genome of M. acerina were designed in the PRIMER 3.0 (http://Frodo.wi.mit.edu/primer3) website [62] based on the screened SSR results. The primers were synthesized by Shuoqing Biological Engineering Technology Co. Ltd.

For the initial screening, 24 isolates from different sources, 118 SSR primers were designed and amplified with $20-\mu \mathrm{L}$ PCR mixtures. All the amplification products were separated on $2.5 \%$ agarose gels in $0.5 \times$ TAE buffer, using a 100-bp DNA ladder as a DNA molecular marker (Raju, Sheshumadhav and Murthy, 2008). The primers with clear, specific, and target bands (100 500 
bp) could be tested by automatic electrophoresis apparatus (Qsep $\left.{ }^{100 T M}\right)$. Finally, the polymorphism of primers was assessed using CERVUS 3.0 [63], and the primers in which PIC exceeded 0.5 were retained for use genetic diversity analyses [64].

\section{SSR analysis of Mycocentrospora acerina genome}

Based on the initial results, 14 primer pairs with high polymorphism in M. acerina populations were selected (MP30, MP36, MP47, MP50, MP51, MP56, MP61, MP62, MP63, MP68, MP84, MP92, MP113, and MP114) for use in amplification reactions. Stable and clear fragments ranging in size between $100 \mathrm{bp}$ and $800 \mathrm{bp}$ were transformed into a binary character matrix $(1=$ presence, $0=$ absence) $[65,66]$.

\section{Statistical analysis}

Genetic diversity parameters of each geographic population, including observed number of alleles, effective number of alleles, Nei's diversity index, Shannon's information index, total gene diversity, intrapopulation gene diversity, the coefficient of gene differentiation, and gene flow [67], were calculated using POPGENE 32 (version 1.32) [68]. NTSYS-pc (version 2.0) was used to calculate genetic similarity coefficient [69]. The phylogenetic tree was analyzed using unweighted pair-group algorithm with arithmetic averages clustering analysis [70].

\section{Abbreviations}

M.acerina: Mycocentrospora acerina

P.notoginseng: Panax notoginseng (Burk.) F. H. Chen

SSR: Simple sequence repeat

ITS: Inter transcribed spacer

PCR: Polymerase chain reaction

MP: Primer of M. acerina

\section{Declarations}

All methods were carried out in accordance with relevant guidelines and regulations.

\section{Ethics approval and consent to participate}

Not applible

\section{Consent for publication}

Not applible

\section{Availability of data and materials}

The datasets generated and/or analysed during the current study are available in the [GeneBank] repository. The genome data of M. acerina generated during the current study are available in NCBI (accession number: PRJNA809504). The SSR data can be downloaded from the website: https://www.ncbi.nlm.nih.gov/WebSub/ 


\section{Author contributions}

Wang huiling, Yang kuan, Zhu youyong and He xiahong contributed to the conception of the study. Wang huiling, Luo lifen, He chi and Li xiang performed the experiment;

Wang huiling and Yang kuan performed the data analyses and wrote the manuscript;

Wang huiling, Guo liwei, Huang huichuan, Liu yixiang, Yang min and Zhu shusheng helped perform the analysis with constructive discussions.

\section{Funding}

National Key Research and Development Project, Grant/Award Number: 2018YFD0201100, Special Foundation for Construction of Modern Agricultural Industrial Technology System, Grant/Award Number: CARS-21, Yunnan Provincial Key Programs of Yunnan Eco-friendly Food International Cooperation Research Center Project under Grant, Grant/Award Number: 2019ZG00901-03.

\section{Acknowledgements}

We gratefully acknowledge financial support from the presented study was funded by National Key Research and Development Project, Special Foundation for Construction of Modern Agricultural Industrial Technology System and Yunnan Provincial Key Programs of Yunnan Eco-friendly Food International Cooperation Research Center Project.

\section{Competing interests}

The authors declare that they have no competing interests.

\section{Author information}

Affiliations

${ }^{1}$ State Key Laboratory for Conservation and Utilization of Bio-Resources in Yunnan, College of Plant Protection, Yunnan Agricultural University, Kunming, Yunnan, China; ${ }^{2}$ Institute of Agricultural Environment and Resources, Yunnan Academy of Agricultural Sciences, Kunming, Yunnan, China; ${ }^{3}$ Southwest Forestry University, Kunming, Yunnan, China

\section{References}

1. Duan L, Xiong XJ, Hu JY, Liu YM, Li J, Wang J. Panax notoginseng saponins for treating coronary artery disease: a functional and mechanistic overview. Frontiers in Pharmacology. 2017; 8, 702. http://doi. org/10.3389/fphar.2017.00702

2. Wan JY, Fan Y, Yu QT, Ge YZ, Yan CP, Alolga RN, et al. Integrated evaluation of malonyl ginsenosides, amino acids and polysaccharides in fresh and processed ginseng. J Pharm Biomed Anal. 2015; 107:89-97. doi: 10.1016/j.jpba.2014.11.014. Epub 2014 Dec 19. PMID: 25575174. http://doi. org/10.1016/j.jpba.2014.11.014

3. Xu QF , Fang XL , Chen DF. Pharmacokinetics and bioavailability of ginsenoside Rb1 and Rg1 from Panax notoginseng in rats. Journal of Ethnopharmacology. 2003; 84(2-3):187-192. http://doi. org/10.1016/S0378-8741(02)00317-3

4. Xia PG, Zhang SC, Liang ZS, Qi ZH. Research history and overview of chemical constituents of Panax notoginseng. Chinese Traditional and Herbal Drugs. 2014; 45(17), 2564-2570. http://doi. org/10.7501/j.issn.0253-2670.2014.17.026

5. Long YJ, Mao ZS, Zhu SS, Chen ZJ, Wei FG, Yin ZB, et al. The pathogen of Panax notoginseng root rust spot. Mycosystema. 2015; 34(2), 177-185. http://doi. org/10.13346/j.mycosystema.140013 
6. Ma YN, Chen CJ, Li QQ, Xu FR, Cheng YX, Dong X. Monitoring antifungal agents of Artemisia annua against Fusarium oxysporum and Fusarium solani, associated with Panax notoginseng root-rot disease. Molecules. 2019; 24(1). http://doi. org/10.3390/molecules24010213

7. Tang BF, Li X, Pu LM, Zhao Q, Cui XM, Ge F, et al. A pathogenesis-related protein 10 gene pnpr10-3 was involved in molecular interaction between Panax notoginseng and Fusarium solani. Australasian Plant Pathology. 2019; 48, 447-456. http://doi. org/10.1007/s13313-019-00644-0

8. Lu N, Chen YJ, Lu HJ, Liu YL. Biological characterization of round spot pathogen on Panax notoginseng. Journal of Yunnan Agricultural University. 2015; 2, 193-195. http://doi. org/10.16211/j.issn.1004-390x(n).2005.02.009

9. Chen YJ, Wang Y, Feng GQ, Liu YZ. Biological characteristics of Alternaria panax whetz isolated from Panax notoginseng. Acta Phytopathologica Sinica. 2005; 3, 267-269. http://doi. org/10.13926/j.cnki.apps.2005.03.013

10. Jiang N, Qin LY, Ye YF. Research advances in diseases of Panax notoginseng. Journal of Southern Agriculture. 2011; 2 , 149-153.

11. Li Y, Long S, Li X. Occurrence of root rot of Panax notoginseng caused by Fusarium oxysporum in China. International Journal of Agriculture and Biology. 2018; 20(10), 2175-2180. http://doi. org/10.17957/IJAB/15.0757

12. Dai L, Xu YL, Long YJ, Du LS, Du YL, He XH. The growth characteristic of mycelia and conidia for Mycocentrospora acerina. Journal of Yunnan Agricultural University (Natural Science). 2017; 32(1), 27-35. http://doi.

org/10.16211/j.issn.1004-390X(n).2017.01.004

13. Wall CJ, Lewis BG. Infection of carrot plants by Mycocentrospora acerina. Transactions of the British Mycological Society. 1980; 74(3), 587-593. http://doi. org/10.1016/S0007-1536(80)80060-X

14. Davies WP, Lewis BG, Day JR. Infection of stored carrot roots by Mycocentrospora acerina (hartig) deighton. Transactions of the British Mycological Society. 1977; 77(1), 139-151. http://doi. org/10.1016/S0007-1536(81)80188-X

15. Garfinkel AR, Chastagner GA. Strategies to address emerging fungal diseases in peony (Paeonia lactiflora) in the united states. Acta horticulturae. 2019; 199-206. http://doi. org/10.17660/ActaHortic.2019.1237.26

16. Ellis MB. Dematiaceous hyphomycetes in Britain. Transactions of the British Mycological Society. 1974; http://doi. org/10.1016/S0007-1536(74)80031-8

17. Hermansen A. Weeds as hosts of Mycocentrospora acerina. Annals of Applied Biology. 2010; 121(3):679-686. http://doi. org/10.1111/j.1744-7348.1992.tb03476.x

18. Wang CW, Fu JF, Wang WK. Brief report on the study of a new disease- the leaf withering disease of Asarum. Journal of Shenyang Agricultural University. 1992; 23(4), 355-356.

19. Chen K, Chen SX, Yu ZW. A new disease on sanqi. Plant Protection. 1997; 1, 49.

20. Cumagun $C$. Population genetic analysis of plant pathogenic fungi with emphasis on Fusarium species[J]. Philippine Agricultural Scientist, 2007, 90(3):244-256.

21. Yu DB. Population genetics of plant pathogens. Plant Protection. 1979; 1, 1-7. http://doi. org/10.1094/PHI-A-2004-0524-01

22. Salama N, Guillemin K, Mcdaniel TK, Sherlock G, Tompkins L, Falkow S. A whole-genome microarray reveals genetic diversity among Helicobacter pylori strains. Proc Natl Acad Sci USA. 2000; 97(26):14668-14673. http://doi. org/10.1073/pnas.97.26.14668

23. Yu XJ, Ren ZH, Liu PK, Zhang ZY, Wang HH, Liu MR. Analysis of genetic diversity of Magnaporthe oryzae in rice blast nursery in Taojiang of Hunan by SSR markers, Southwest China Journal of Agricultural Sciences. 2018; 31(04), 725-730. http://doi. org/10.16267/j.cnki.1005-3956.2014.03.002

24. Bridge PD, Singh T, Arora DK. (2003) The application of molecular markers in the epidemiology of plant pathogenic fungi. Mycology. 2003; http://doi. org/10.1201/9780203913369.ch5

25. Barus H, Bayu E, Hanafiah D. Identification genetic of soybean mutant (Glycine max L. Merril) based on fatty acid characters using simple sequence repeat (SSR) markers. The 3rd International Conference Community Research and Service Engagements. 2020; http://doi. org/10.4108/eai. 4-12-2019.2293861 
26. Adjebeng-Danquah J, Manu-Aduening J, Asante IK, Agyare RY, Offei SK. Genetic diversity and population structure analysis of ghanaian and exotic cassava accessions using simple sequence repeat (SSR) markers. Heliyon. 2020; http: //doi. org/ 10.1016/j.heliyon.2019.e03154

27. Crauwels S, Zhu B, Steensels J, Busschaert P, Lievens B. Assessing genetic diversity among Brettanomyces yeasts by DNA fingerprinting and whole-genome sequencing. Applied and Environmental Microbiology, 2014, 80(14):4398-4413. http://doi. org/10.1128/AEM.00601-14

28. Colling G, Matthies D. The effects of plant population size on the interactions between the endangered plant Scorzonera humilis, a specialised herbivore, and a phytopathogenic fungus. Oikos. 2010; 105(1), 71-78. http://doi. org/10.1111/j.0030-1299.2004.12783.x

29. Mcgrath M T, Shishkoff N . Resistance to Triadimefon and Benomyl: Dynamics and Impact on Managing Cucurbit Powdery Mildew[J]. Plant Disease, 2001, 85(2):147-154. http://doi. org/10.1094/PDIS.2001.85.2.147

30. Fernández-Ortuño D, Pérez-García A, López-Ruiz F, Romero D, Vicente AD, Torés JA. Occurrence and distribution of resistance to Qoi fungicides in populations of podosphaera fusca in south central Spain. European Journal of Plant Pathology. 2006; 115(2), 215-222. http://doi. org/10.1007/s10658-006-9014-7

31. Catherine JW, Lewis BG. Infection of carrot plants by Mycocentrospora acerina. Transactions of the British Mycological Society. 1980; 74(3), 587-593. http://doi. org/10.1016/S0007-1536(80)80060-X

32. Louarn S, Nawrocki A, Edelenbos M, Dan FJ, Jensen ON, Collinge DB. The influence of the fungal pathogen Mycocentrospora acerina on the proteome and polyacetylenes and 6-methoxymellein in organic and conventionally cultivated carrots (Daucus carota) during post harvest storage. Journal of proteomics. 2012; 75(3), 962-77. http://doi. org/10.1016/j.jprot.2011.10.014

33. Luo HY, Wang XJ, Zhan GM, Wei GR, Zhou XL, Zhao J. et al. Genome-wide analysis of simple sequence repeats and efficient development of polymorphic SSR markers based on whole genome re-sequencing of multiple isolates of the wheat stripe rust fungus. Plos One. 2015; http://doi. org/10.1371/journal.pone.0130362

34. Sharopova N, McMullen MD, Schultz L, Steve S, Hector SV, Jack G. et al. Development and mapping of SSR markers for maize. Plant Mol Biol. 2002; 48, 463-481. http://doi. org/ 10.1023/A:1014868625533

35. Toth G. Microsatellites in Different Eukaryotic Genomes: Survey and Analysis. Genome Research, 2000; 10(7):967. http://doi. org/ info:doi/10.1111/j.1467-9523.2006.00401.x

36. Velasco R, Zharkikh A, Troggio M, Cartwright DA, Cestaro A, Pruss D. et al. A high quality draft consensus sequence of the genome of a Heterozygous grapevine variety, PLoS ONE. 2007; http://doi. org/10.1371/journal.pone.0001326

37. Sia EA, Kokoska RJ, Dominska M, Greenwell P, Petes TD. Microsatellite instability in yeast: dependence on repeat unit size and DNA mismatch repair genes. Molecullar and Cellular Biology. 1997; 17(5), 2851-2858. http://doi.

org/10.1128/MCB.17.5.2851

38. Mccouch SR, Teytelman L, Xu Y, Katarzyna BL, Karen C, Mark W, et al. Development and mapping of 2240 new SSR markers for rice (Oryza sativa L.) (supplement). DNA Res. 2002; 9(6), 257-279. http://doi. org/10.1093/dnares/9.6.257

39. Cho YG, Ishii T, Temnykh S, Chen X, Lipovich XL, Mccouch SR, et al. Diversity of microsatellites derived from genomic libraries and GenBank sequences in rice (Oryza sativaL.). Theoretical \& Applied Genetics. 2000; 100, 713-722. http://doi. org/10.1007/s001220051343

40. Lu XW, Brewbaker JL. Molecular mapping of QTLs conferring resistance to Sphacelotheca reiliana (kühn) clint. Maize Genetics Cooperation Newsletter. 1999; 73, 36.

41. Liu C, Li J, Qin G. Genome-wide distribution of simple sequence repeats in pomegranate and their application to the analysis of genetic diversity. Tree Genetics \& Genomes. 2020; https://doi.org/10.1007/s11295-020-1428-4

42. Wei HL, Edo K. Evolutionary pressures on simple sequence repeats in prokaryotic coding regions. Nucleic Acids Research. 2011; 6, 6. http://doi. org/10.1093/nar/gkr1078

43. Xie WG, Zhang XQ, Ma X, Peng Y, Huang LK. Genetic variation and relationship in orchard grass (Dactylis glomerata I.) germplasm detected by ssr markers. Hereditas (Bjing). 2009; 31(6), 654-662. http://doi.

org/10.3724/SP.J.1005.2009.00654

Page 11/23 
44. Zhou YY, Wang LQ, Fu YL, Yang LQ. A review of research on biological genetic resources and traditional knowledge. Journal of Northeast Agricultural University(Social Science Edition). 2017; 16(01), 60-70.

45. Sun T, Kong LW, Wang MM, Jin PY, Hong XY. Development and characterization of novel EST-microsatellites for the citrus red mite, Panonychus citri (Acari: Tetranychidae), Systematic and Applied Acarology. 2014; 14(9), 499. http://doi. org/10.11158/saa.19.4.13

46. Sun TT, Wang DW, Chen L, Wang WF, Gong DP, Chen YQ, et al. Characteristics and distribution of SSR loci in the coding region of potato genome and functional analysis of their encoding proteins. Molecular Plant Breeding. 2015; 13(01), 171177. http://doi. org/10.13271/j.mpb.013.000171

47. Liu XF, Yuan WY, Liang D, Shi XW, Ma ZH. Population genetic structures of Puccinia striiformis f. sp.tritici in Yunnan and Guizhou province. Journal of Yunnan Agricultural University (Natural Science). 2016; 49(6), 95-100. http://doi. org/10.16211/j.issn.1004-390X(n).2016.05.002

48. Iwano M, Lee JL, Lee CY. Distribution of pathogenic races and changes in virulence of rice blast fungus, pyricularia oryzae cav. in Yunnan province, china. Jarq. 1990; 23(3), 241-248. http://doi. org/10.1071/EA9900853

49. Wu H, Liu BL, Wang WH, Shi YM, Wei SF, Zhou H. Genetic diversity analysis of male sterile lines for three-line hybrid rice mainly applied in Guangxi. Journal of Southern Agriculture. 2015; 46(04), 550-554.

50. Mao YX, Zhang XL, Hu ZJ, Zhao Y. Genetic diversity of Trachycarpus fortunei (Hook.) H. Wendl germplasm resources in Guizhou by SRAP molecular markers analysis. Journal of Southern Agriculture. 2020; 51(1), 27-35.

51. Li YF, Zhang XL, Liao XG, Zhang D. Evaluation study of multiplex PCR assay for detection diarrheagenic Escherichia coli. Henan Journal of Preventive Medicine. 2014; https://doi.org/10.13515/j.cnki.hnjpm.2014.02.040

52. Ferrucho RL, Ceresini PC, Ramírez-Escobar UM, Mcdonald BA, García-Domínguez, C. The population genetic structure of rhizoctonia solani AG-3PT from potato in the Colombian andes. Phytopathology. 2013; 103(8), 862-869. http://doi. org/10.1094/PHYTO-11-12-0278-R

53. Cumagun CJR. Population genetic analysis of plant pathogenic fungi with emphasis on Fusarium species. Philippine Agricultural entist. 2007; 90(3), 244-256.

54. Evenhuis A, Verdam B, Zadoks JC. Splash dispersal of conidia of Mycocentrospora acerina in the field. Plant Pathology. 2010; 46(4), 459-469. http://doi. org/10.1046/j.1365-3059.1997.d01-42.x

55. Mcdermott JM, Mcdonald BA. Gene flow in plant pathosystems. Annual Review of Phytopathology. 1993; 31(1), 353373. http://doi. org/10.1146/annurev.py.31.090193.002033

56. Wang HL, Wang F, Jin BH, Zhang H, Yang K, Wang WP, et al. Sensitivity and fitness analysis of round spot of Panax notoginsen Mycocentrospora acerina to azoxystrobin, prochloraz and difenoconazoleg. Chinese Journal of Pesticide Science. 2019; 21(3), 273-278. http://doi. org/10.16801/j.issn.1008-7303.2019.0037

57. Wang WY, Zhao CL, Chen ZJ, Wen GS, Wei FG, Long TJ, et al. Studies on the isolation, identification and in vitro growth rates of the three pathogenic fungi from Panax notoginseng cultivated in Wenshan eparchy. Agricultural Science Technology. 2015; 16(6), 1165. http://doi. org/10.16175/j.cnki.1009-4229.2015.06.018

58. Li H, Li J, Xu R, Qin RY, Song FS, Li L, et al. Isolation of five rice non-endosperm tissue-expressed promoters and evaluation of their activities in transgenic rice. Plant Biotechnology Journal. 2018; 16(6):1138-1147. http://doi.

org/10.1111/pbi.12858

59. Wang Z, Zheng QM, Cheng WT, Mao YY, Cai YQ, Ma YH. Information analysis and molecular marker development of transcriptome SSR in Pitaya. Guizhou Agricultural sciences. 2018; 46(07), 1-5.

60. Wang X, Chen L, Zhao CL. Mining SSR Molecular Marker Sites with MISA Tool for Different Types of Sequences. Chinese Agricultural Science Bulletin. 2016; 32(10), 150-156.

61. Xu D, Chen H, Aci M, Pan Y, Shangguan Y, Ma J, et al. De Novo assembly, characterization and development of EST-SSRs from Bletilla striata transcriptomes profiled throughout the whole growing period. PLoS ONE, 2018, 13(10). http://doi. org/10.1371/journal.pone.0205954 
62. Hou LX, Wei AZ, Wang LH, Liu YL. Analysis of SSR loci and development of molecular markers in Zanthoxylum bungeanum transcriptome. Journal of Agricultural Biotechnology. 2018; 26(7), 1226-1236.

63. Azam, Amirian, Zahra, Zafari, Zohreh, Sharifi, et al. Characterization and haplotype study of 6 novel STR markers related to the KCNQ1 genein heterogeneous cardiovascular disorders in the Iranian population. Turkish Journal of Medical Sciences, 2019. http://doi. org/10.3906/sag-1805-43

64. Zhou XJ, Wang HL, Li FL, Zhang K, Wang YN, Ya HY, et al. Development of polymorphic ssr markers in Rhododendron henanense subsp. lingbaoense based on rad-seq. Journal of Agricultural Biotechnology. 2019; 27(01), 55-62.

65. Zeng XQ, Wang YL, Xu QJ, Yuan HJ, Zaxi L, Ni M. Assessment of genetic diversity in tibetan hulless barley germplasm(Hordeum vulgare L. var. nudum hk.f.) by ssr primers. Journal of Triticeae Crops. 2013; 33(02), 260-267.

66. Ei-Komy, Saleh, Molan A. Molecular characterization of early blight disease resistant and susceptible potato cultivars using RAPD and SSR markers. African Journal of Biotechnoogy. 2012; http://doi. org/10.5897/AJB11.2709

67. Yu Z , Yan X , Zhang Y, Yang F, Zhang Z. Genetic diversity analysis of different age of a Dalian population of the Manila clam Ruditapes philippinarum by EST-SSR[J]. Acta Ecologica Sinica, 2012, 32(15):4673-4681. http://doi. org/10.5846/stxb201105150625

68. Liu R, YANG JS. Genetic diversity of some Dendranthema spp. based on RAPD analysis. Journal of Agricultural University of Heb. 2010; 33(1), 60-65+83.

69. Gaikwad AB, Behera TK, Singh AK. Chandel D, Karihaloo JL, Staub JE. Amplified fragment length polymorphism analysis provides strategies for improvement of bitter gourd (Momordica charantia L.). Acta Horticulturae. 2008; 871, 71-78. http://doi. org/10.17660/ActaHortic.2010.871.7

70. Wang ZJ, Wu W, Hu B, Zhang HL, Bai X, Zhao JJ, et al. Molecular epidemiology of Aleutian mink disease virus in China. Virus Research. 2014; 184, 14-19. http://doi. org/10.1016/j.virusres.2014.02.007

\section{Tables}

\section{TABLE 1}

Mycocentrospora acerina populations examined in the simple sequence repeat analysis. 


\begin{tabular}{|c|c|c|c|c|c|}
\hline Location & ID & Population & Isolates & Latitude (N) & Longitude (E) \\
\hline \multirow[t]{5}{*}{ Honghe $(\mathrm{HH})$} & SC & Shaochong, Honghe & 4 & $23^{\circ} 54^{\prime} 30^{\prime \prime}$ & $102^{\circ} 27^{\prime} 53^{\prime \prime}$ \\
\hline & LP & Longpeng, Honghe & 4 & $23^{\circ} 58^{\prime} 12^{\prime \prime}$ & $102^{\circ} 34^{\prime} 13^{\prime \prime}$ \\
\hline & JS & Jianshui, Honghe & 15 & $23^{\circ} 24^{\prime} 22^{\prime \prime}$ & $102^{\circ} 49^{\prime} 58^{\prime \prime}$ \\
\hline & LX & Luxi, Honghe & 15 & $24^{\circ} 41^{\prime} 14^{\prime \prime}$ & $103^{\circ} 51^{\prime} 10^{\prime \prime}$ \\
\hline & $\mathrm{MZ}$ & Mengzi, Honghe & 3 & $23^{\circ} 37^{\prime}$ & $103^{\circ} 40^{\prime}$ \\
\hline Puer (PE) & $\mathrm{L}$ & Lancang, Puer & 15 & $22^{\circ} 40^{\prime} 29^{\prime \prime}$ & $99^{\circ} 50^{\prime} 49^{\prime \prime}$ \\
\hline \multirow[t]{6}{*}{ Wenshan (WS) } & YS & Yanshan, Wenshan & 2 & $23^{\circ} 23^{\prime} 4^{\prime \prime}$ & $104^{\circ} 16^{\prime} 24^{\prime \prime}$ \\
\hline & WS & Wenshan, Wenshan & 3 & $23^{\circ} 14^{\prime} 30^{\prime \prime}$ & $104^{\circ} 5^{\prime} 0^{\prime \prime}$ \\
\hline & DM & Dumeng, Wenshan & 6 & $23^{\circ} 15^{\prime} 42^{\prime \prime}$ & $104^{\circ} 8^{\prime} 42^{\prime \prime}$ \\
\hline & $\mathrm{QL}$ & Qiubei, Wenshan & 7 & $23^{\circ} 56^{\prime} 25^{\prime \prime}$ & $103^{\circ} 48^{\prime} 21^{\prime \prime}$ \\
\hline & QX & Qiubei, Wenshan & 16 & $23^{\circ} 50^{\prime} 2^{\prime \prime}$ & $104^{\circ} 6^{\prime} 10^{\prime \prime}$ \\
\hline & QS & Qiubei, Wenshan & 6 & $23^{\circ} 50^{\prime} 23^{\prime \prime}$ & $104^{\circ} 6^{\prime} 34^{\prime \prime}$ \\
\hline \multirow[t]{2}{*}{ Qujing (QJ) } & SZ & Shizong, Qujing & 16 & $24^{\circ} 75^{\prime} 44^{\prime \prime}$ & $103^{\circ} 91^{\prime} 78^{\prime \prime}$ \\
\hline & LS & Luoping, Qujing & 16 & $24^{\circ} 47^{\prime} 47^{\prime \prime}$ & $104^{\circ} 17^{\prime} 36^{\prime \prime}$ \\
\hline \multirow[t]{2}{*}{ Kunming (KM) } & SL & Shilin, Kunming & 12 & $24^{\circ} 48^{\prime} 31^{\prime \prime}$ & $103^{\circ} 38^{\prime} 16^{\prime \prime}$ \\
\hline & $X D$ & Xundian, Kunming & 20 & $25^{\circ} 44^{\prime} 48^{\prime \prime}$ & $103^{\circ} 21^{\prime}$ \\
\hline Lijiang (LJ) & LJ & Lijiang & 7 & $26^{\circ} 86^{\prime}$ & $100^{\circ} 25^{\prime}$ \\
\hline
\end{tabular}

TABLE 2

SSR Primers of the whole genome of Mycocentrospora acerina 


\begin{tabular}{|c|c|c|c|c|c|c|}
\hline Locus & $\begin{array}{l}\text { Repeat } \\
\text { Motif }\end{array}$ & Primer sequence & $\begin{array}{l}\text { Size } \\
\text { (bp) }\end{array}$ & $\begin{array}{l}\text { Expected } \\
\text { Heterozygosity } \\
(\mathrm{He})\end{array}$ & $\begin{array}{l}\text { Polymorphic } \\
\text { Information } \\
\text { Content } \\
\text { (PIC) }\end{array}$ & $\begin{array}{l}\text { Annealing } \\
\text { Temperature } \\
\text { (Tm) }\end{array}$ \\
\hline \multirow[t]{2}{*}{ MP40 } & \multirow[t]{2}{*}{$(\mathrm{CTA})_{27}$} & F: CACATGCTCAGTCATTTGTGG & \multirow[t]{2}{*}{243} & \multirow[t]{2}{*}{0.681} & \multirow[t]{2}{*}{0.599} & \multirow[t]{2}{*}{56} \\
\hline & & R: GGTGCAATCGGAAAGAATTG & & & & \\
\hline \multirow[t]{2}{*}{ MP42 } & \multirow[t]{2}{*}{$(\mathrm{TC})_{19}$} & F: AAGCGCACTTGCCTATTGAT & \multirow[t]{2}{*}{225} & \multirow[t]{2}{*}{0.609} & \multirow[t]{2}{*}{0.53} & \multirow[t]{2}{*}{58.4} \\
\hline & & R: GGTGAGTGTTGCTGACGAAA & & & & \\
\hline \multirow[t]{2}{*}{ MP2 } & \multirow[t]{2}{*}{$(\mathrm{CAT})_{14}$} & F: CGTCCATCTTCCTCTTCACC & \multirow[t]{2}{*}{200} & \multirow[t]{2}{*}{0.71} & \multirow[t]{2}{*}{0.622} & \multirow[t]{2}{*}{56.4} \\
\hline & & R: GCTCATGTTCGATGGATGTG & & & & \\
\hline \multirow[t]{2}{*}{ MP49 } & \multirow{2}{*}{$(\mathrm{GA})_{25}$} & F: GGAAGGAAATCCAGGTGTGA & \multirow[t]{2}{*}{200} & \multirow[t]{2}{*}{0.594} & \multirow[t]{2}{*}{0.505} & \multirow[t]{2}{*}{56} \\
\hline & & R: CCCACTTCCTGTTTGCTTGT & & & & \\
\hline \multirow[t]{2}{*}{ MP54 } & \multirow[t]{2}{*}{$(\mathrm{CAA})_{19}$} & F: GTTGTTGCCAGCAAGAGTGA & \multirow[t]{2}{*}{199} & \multirow[t]{2}{*}{0.623} & \multirow[t]{2}{*}{0.552} & 58.4 \\
\hline & & R: AACAACCCTGGCACTACTCG & & & & \\
\hline MP55 & $(\text { TTGA })_{19}$ & F: ТTССтстсСстстссстстс & 214 & 0.623 & 0.552 & 59 \\
\hline & & R: ATGCTGCAAGTCTGTTGACG & & & & \\
\hline MP56 & $(\mathrm{TAG})_{25}$ & F: TGTGTGTGTGTTGTTGTTGTTG & 228 & 0.87 & 0.812 & 59.5 \\
\hline & & R: TGACAAGCAAGTAGATTTTTACGTTT & & & & \\
\hline MP4 & $(\mathrm{GACA})_{6}$ & F: AGGGTAGCTCAAAGCCACTG & 273 & 0.725 & 0.665 & 58.4 \\
\hline & & R: CTTTCCAAGCTGAGGGTGAG & & & & \\
\hline MP58 & $(\mathrm{GA})_{25}$ & F: TCGTTTTTGGAGCGTTCTTT & 209 & 0.739 & 0.659 & 54.4 \\
\hline & & R: TGGACGCACTCCTTCTTTTC & & & & \\
\hline MP52 & $(\mathrm{CCA})_{11}$ & F: GCTTCGGTGTCTGGAATCAT & 179 & 0.609 & 0.53 & 56.4 \\
\hline & & R: AAACTTCAATGTCGCCAAGG & & & & \\
\hline MP51 & $(\mathrm{TTG})_{19}$ & F: CGTCTCTGTTATTGCTGCTTT & 159 & 0.826 & 0.76 & 55.7 \\
\hline & & R: CGCACAACCAATGAGAAACA & & & & \\
\hline MP 13 & $(\mathrm{AGT})_{12}$ & F: CACGTCACGGAGCAAGTAGA & 211 & 0.696 & 0.622 & 57.4 \\
\hline & & R: TGATGAGGTCCAACGGAGAT & & & & \\
\hline MP3 & $(\mathrm{GT})_{13}$ & F: CATGTGCATTGCTGTGTTGT & 170 & 0.725 & 0.644 & 61.4 \\
\hline & & R: CAGCGAGTGAATGGAAGTGA & & & & \\
\hline MP50 & $(\mathrm{CTGT})_{19}$ & F: GCTTTACTTTGCCCGTCTGT & 200 & 0.768 & 0.701 & 55.4 \\
\hline & & R: TGCATCTCCTCACATCCATC & & & & \\
\hline MP65 & $(\mathrm{CA})_{22}$ & F: АССТССАСАССТGСАССТАС & 245 & 0.609 & 0.53 & 59.5 \\
\hline & & R: GCGGGCTTGTAGTCGTAGAG & & & & \\
\hline MP68 & $(\mathrm{CAT})_{7}$ & F: GGATATGCCTCACCATTTGC & 166 & 0.797 & 0.739 & 55.4 \\
\hline & & R: ATATGGAAGGCCGCAGTGTA & & & & \\
\hline
\end{tabular}




\begin{tabular}{|c|c|c|c|c|c|c|}
\hline Locus & $\begin{array}{l}\text { Repeat } \\
\text { Motif }\end{array}$ & Primer sequence & $\begin{array}{l}\text { Size } \\
\text { (bp) }\end{array}$ & $\begin{array}{l}\text { Expected } \\
\text { Heterozygosity } \\
\text { (He) }\end{array}$ & $\begin{array}{l}\text { Polymorphic } \\
\text { Information } \\
\text { Content } \\
\text { (PIC) }\end{array}$ & $\begin{array}{l}\text { Annealing } \\
\text { Temperature } \\
\text { (Tm) }\end{array}$ \\
\hline \multirow[t]{2}{*}{ MP83 } & $(\mathrm{CTT})_{12}$ & F: TGAGCAGGGGCCAAATACTA & 156 & 0.779 & 0.702 & 54.4 \\
\hline & $(\text { ATGA })_{10}$ & R: TTAAATTCCСАTСCССАТCC & & & & \\
\hline \multirow[t]{2}{*}{ MP36 } & \multirow[t]{2}{*}{$(\mathrm{CAT})_{17}$} & F: ATCTGTCACCACCATCACCA & 193 & 0.87 & 0.812 & 59 \\
\hline & & R: AGCTCGCGATCTAAACATCC & & & & \\
\hline \multirow[t]{2}{*}{ MP39 } & \multirow[t]{2}{*}{$(\mathrm{AGTG})_{24}$} & F: ATGTGTGTGTGTGCCTGGAT & 247 & 0.594 & 0.505 & 60 \\
\hline & & R: TATATGCCCATTCCCATTCC & & & & \\
\hline \multirow[t]{2}{*}{ MP46 } & \multirow[t]{2}{*}{$(\mathrm{CACT})_{10}$} & F: TTCCTCTGACGCATCCTCTT & 207 & 0.638 & 0.535 & 60 \\
\hline & & R: TGGGCATGTAATGAGTGGTG & & & & \\
\hline \multirow[t]{2}{*}{ MP47 } & \multirow[t]{2}{*}{$(\mathrm{CAGG}) 7$} & F: GATTGTAAGCCGCAGAAGGT & 247 & 0.754 & 0.68 & 60 \\
\hline & & R: TCACGACTCCATCACTCCAA & & & & \\
\hline \multirow[t]{2}{*}{ MP20 } & \multirow[t]{2}{*}{$(\text { TACA })_{11}$} & F: TGTGTCGCTCACTCACTCAA & 239 & 0.754 & 0.671 & 59 \\
\hline & & R: GGAAGGAGTGGAGTTGATGG & & & & \\
\hline \multirow[t]{2}{*}{ MP90 } & \multirow[t]{2}{*}{$(\mathrm{TC})_{18}$} & F: TCAAAACCGAAACCCAGAAA & 191 & 0.551 & 0.503 & 55.4 \\
\hline & & R: GGGAGAAGAAGGGCAGAGG & & & & \\
\hline \multirow[t]{2}{*}{ MP108 } & $(\mathrm{TCG})_{10}$ & F: TCACТАССССТАСССССТTТ & 237 & 0.681 & 0.599 & 57.4 \\
\hline & $(\mathrm{TCA})_{5}$ & R: CGGTCGGCATAGGGTATTTA & & & & \\
\hline \multirow[t]{2}{*}{ MP92 } & \multirow[t]{2}{*}{$(\mathrm{CTA})_{31}$} & F: АССССААСАСТСААТСАТСC & 219 & 0.71 & 0.643 & 54.7 \\
\hline & & R: TCTGGCAAGAAGAAGAAATGC & & & & \\
\hline \multirow[t]{2}{*}{ MP62 } & \multirow[t]{2}{*}{$(\mathrm{CTA})_{20}$} & F: CAGAAAATCCTAGCTACTGCTGCT & 174 & 0.725 & 0.644 & 56.5 \\
\hline & & R: TGCAGTCTCTTCACCCTGTTT & & & & \\
\hline \multirow[t]{2}{*}{ MP84 } & \multirow[t]{2}{*}{$(A G A)_{18}$} & F: TTCAATCGTGCAAGGTGTGT & 167 & 0.739 & 0.686 & 58 \\
\hline & & R: GAGAGGAGCAGGGCATGTAG & & & & \\
\hline \multirow[t]{2}{*}{ MP115 } & \multirow[t]{2}{*}{$(\mathrm{AC})_{7}(\mathrm{TC})_{12}$} & F: TCTGCTGCCATGTAGTGCTC & 246 & 0.768 & 0.692 & 55.4 \\
\hline & & R: ATGTGATTTTGGGGGAAACA & & & & \\
\hline \multirow[t]{2}{*}{ MP63 } & \multirow[t]{2}{*}{$(\mathrm{TC})_{21}$} & F: CAGACTTCCCAGTCACCACA & 195 & 0.797 & 0.726 & 55.5 \\
\hline & & R: TTGGCTACTACTGCACCAAAAA & & & & \\
\hline \multirow[t]{2}{*}{ MP113 } & \multirow[t]{2}{*}{$(\mathrm{TG})_{7}(\mathrm{AG})_{10}$} & F: САТСТСТСАТСTСCCCAGGA & 225 & 0.812 & 0.746 & 57.4 \\
\hline & & R: AATCCCATCACACGCTTCTC & & & & \\
\hline \multirow[t]{2}{*}{ MP114 } & $(\mathrm{CTC})_{9}$ & F: GATGTGCAGAGTTTCGGTCA & 232 & 0.913 & 0.862 & 55.4 \\
\hline & $(\mathrm{TTC})_{8}$ & R: GGAAGCTGATTCATCCCAGT & & & & \\
\hline \multirow[t]{2}{*}{ MP61 } & \multirow[t]{2}{*}{$(\mathrm{CA})_{36}$} & F: TGGTGGCTAGTTGGTTGGAT & 212 & 0.928 & 0.878 & 56.4 \\
\hline & & R: GGTCGTCACTGTTGCTTGAA & & & & \\
\hline
\end{tabular}




\section{TABLE 3}

Genetic diversity of geographic populations of Mycocentrospora acerina

\begin{tabular}{|lllll|}
\hline Population & $\mathrm{Na}$ & $\mathrm{Ne}$ & Nei's genetic diversity & Shannon's information index \\
\hline Qujing & 1.6892 & 1.1108 & 0.0888 & 0.1658 \\
\hline Honghe & 1.8041 & 1.1089 & 0.0896 & 0.1712 \\
\hline Kunming & 1.7297 & 1.1103 & 0.0891 & 0.1674 \\
\hline Puer & 1.6892 & 1.1099 & 0.0893 & 0.1676 \\
\hline Lijiang & 1.4122 & 1.1187 & 0.0842 & 0.143 \\
\hline Wenshan & 1.777 & 1.1099 & 0.0893 & 0.1693 \\
\hline
\end{tabular}

TABLE 4

Nei' genetic identity (above diagonal) and genetic distance (below diagonal) of geographic populations of Mycocentrospora acerina

\begin{tabular}{lllllll} 
popID & Honghe & Lijiang & Puer & Kunming & Wenshan & Qujing \\
\hline Honghe & $\star \star \star \star$ & 0.9938 & 0.9976 & 0.9988 & 0.9982 & 0.9977 \\
\hline Lijiang & 0.0062 & $\star \star \star *$ & 0.9931 & 0.9937 & 0.9959 & 0.9946 \\
\hline Puer & 0.0024 & 0.007 & $\star \star \star \star$ & 0.9975 & 0.998 & 0.9978 \\
\hline Kunming & 0.0012 & 0.0064 & 0.0025 & $\star \star \star \star$ & 0.9979 & 0.9975 \\
\hline Wenshan & 0.0018 & 0.0041 & 0.002 & 0.0021 & $\star \star \star \star$ & 0.9983 \\
\hline Qujing & 0.0024 & 0.0054 & 0.0022 & 0.0025 & 0.0017 & $\star \star \star \star$
\end{tabular}

\section{Figures}




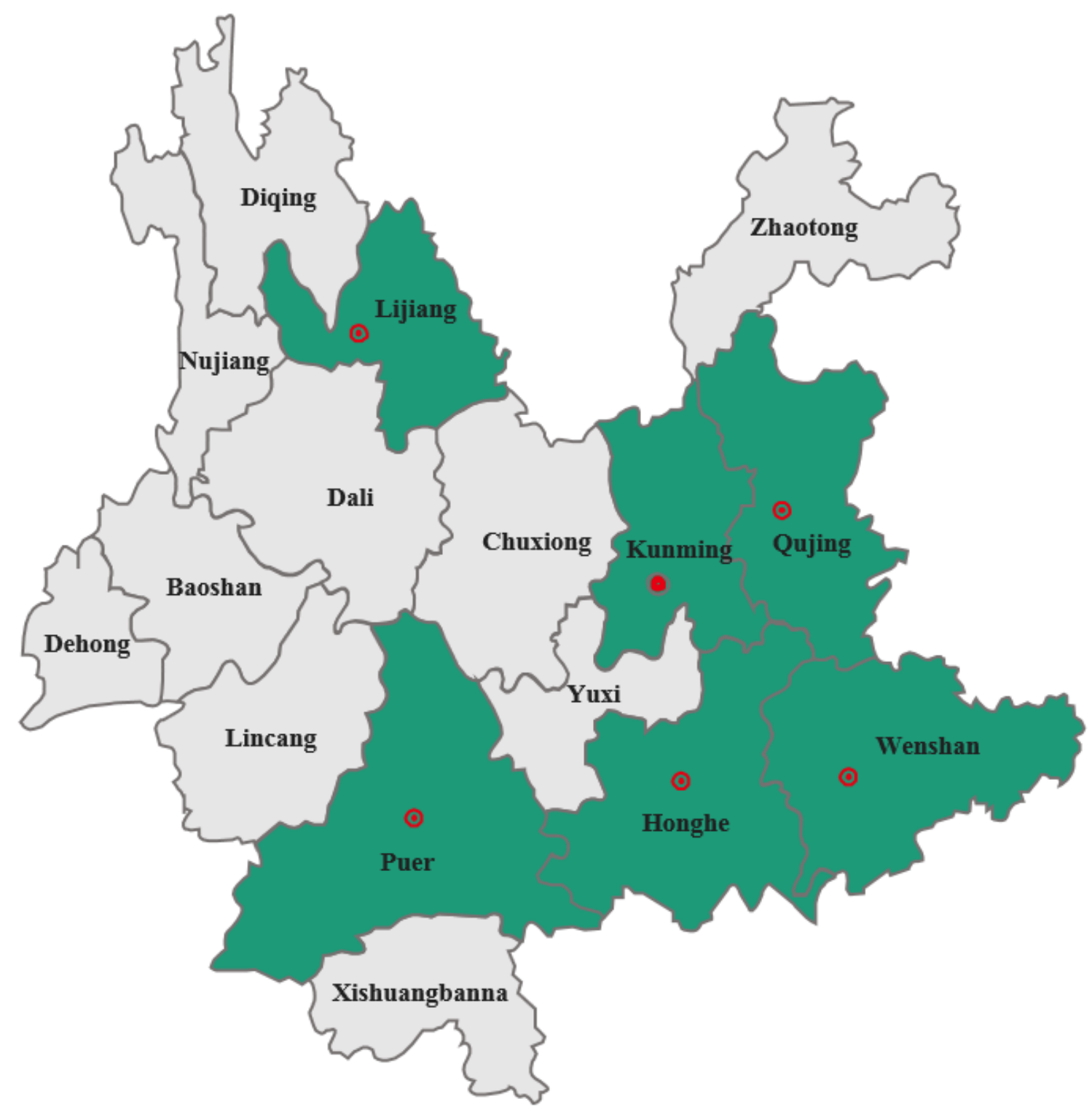

Figure 1

The geographical locations of six Mycocentrospora acerina populations in Yunnan(green region). 


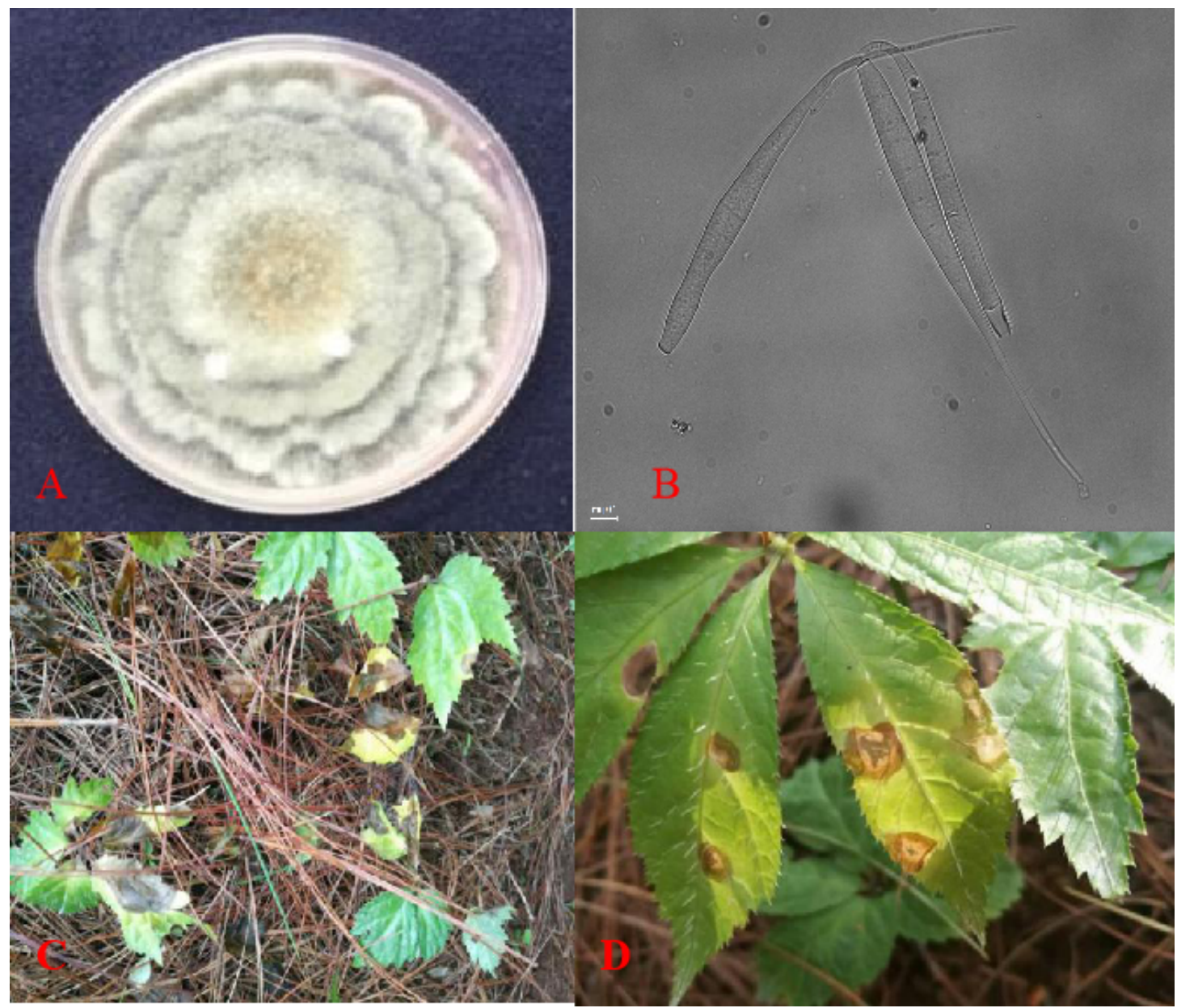

Figure 2

Mycocentrospora acerina colonies (A), conidia (B), and symptoms (C, D) in the field. 


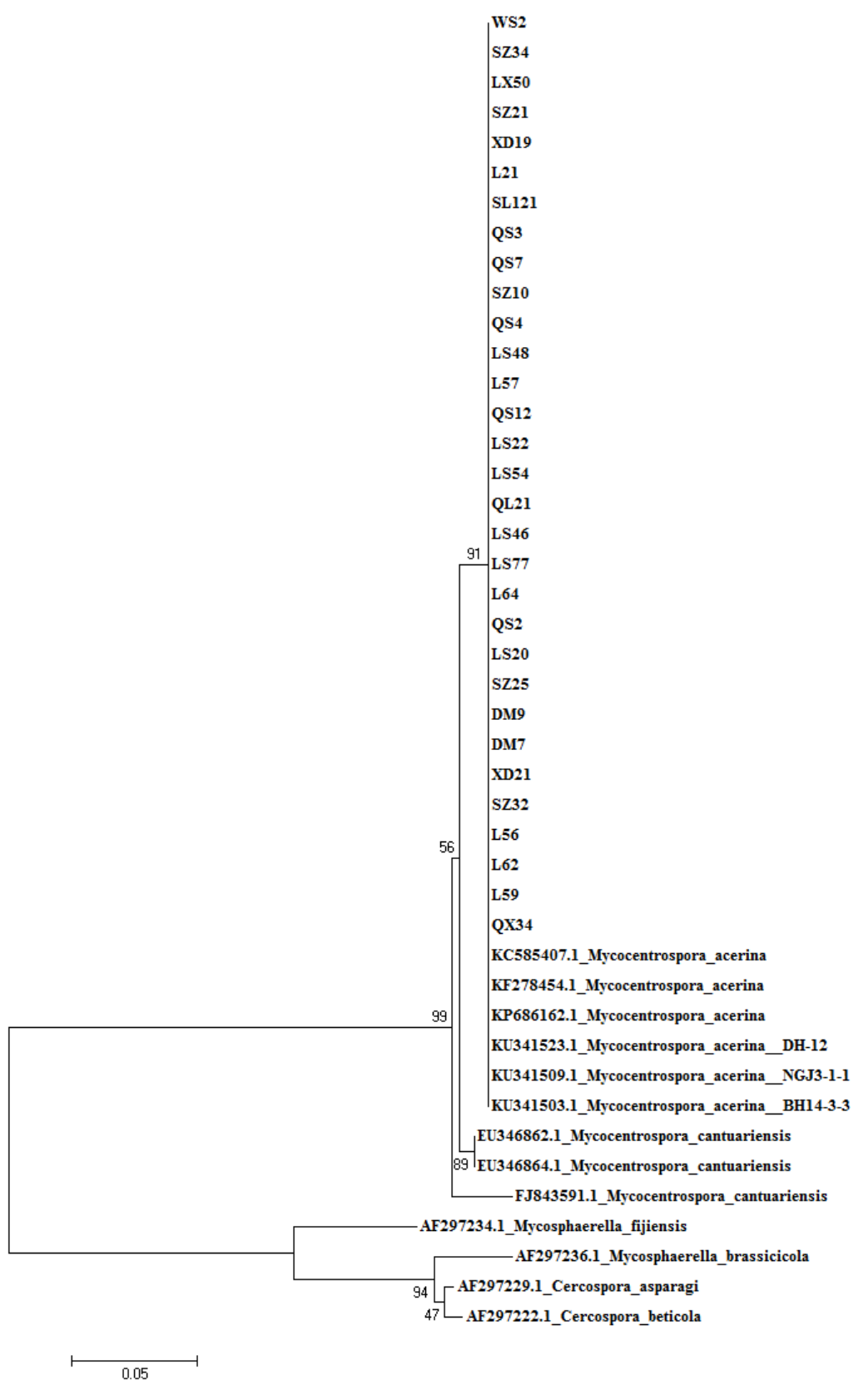

Figure 3

Phylogenetic tree constructed based on internal transcribed spacer1 (ITS1)sequences. 


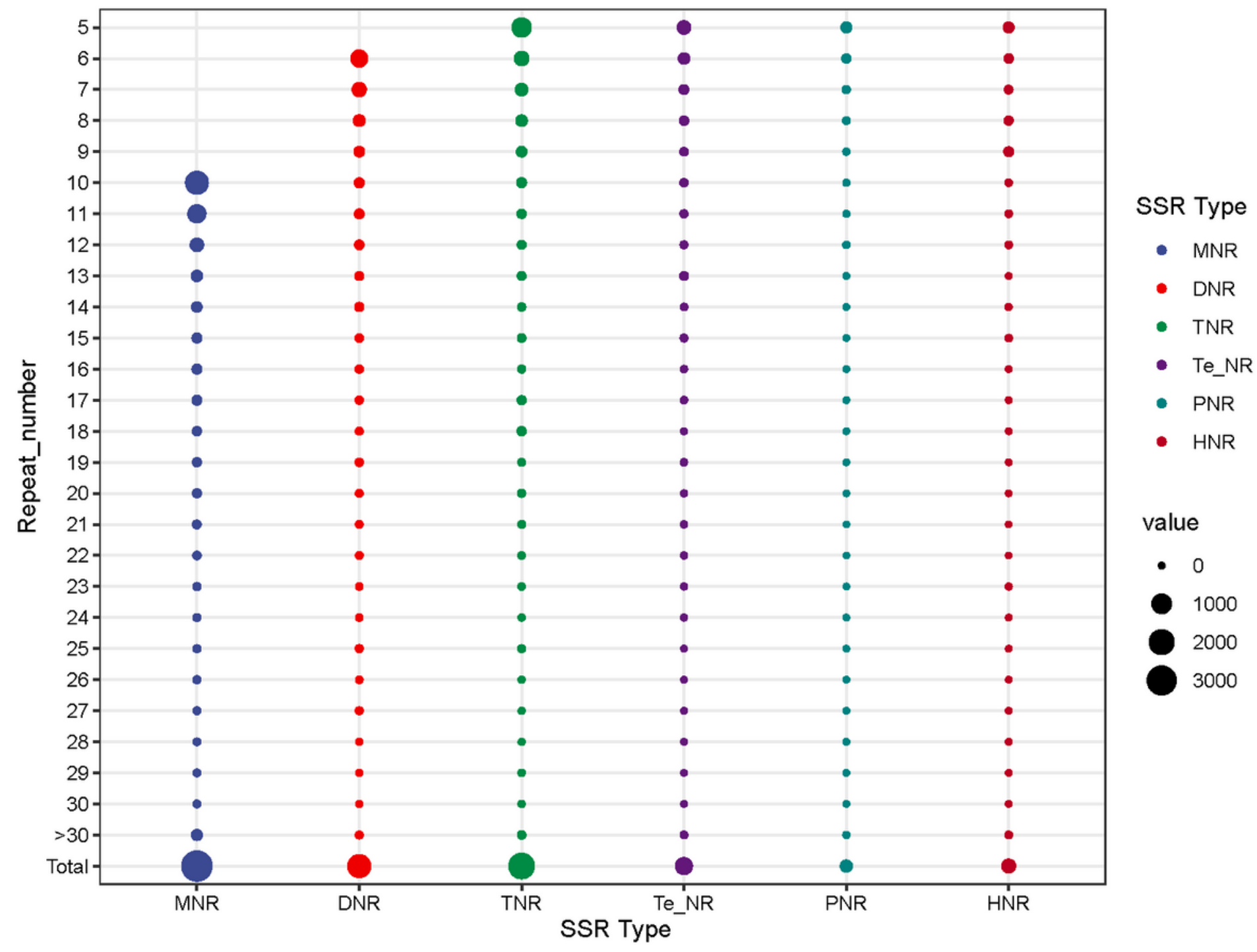

Figure 4

Distributions and frequencies of simple sequence repeats (SSRs) in Mycocentrospora acerina.mono-nucleotide repeats, DNR: di-nucleotide repeats; TNR: tri-nucleotide repeats, Te_NR: tetra-nucleotide repeats, PNR: penta-nucleotide repeats, HNR: hexanucleotide repeats. 


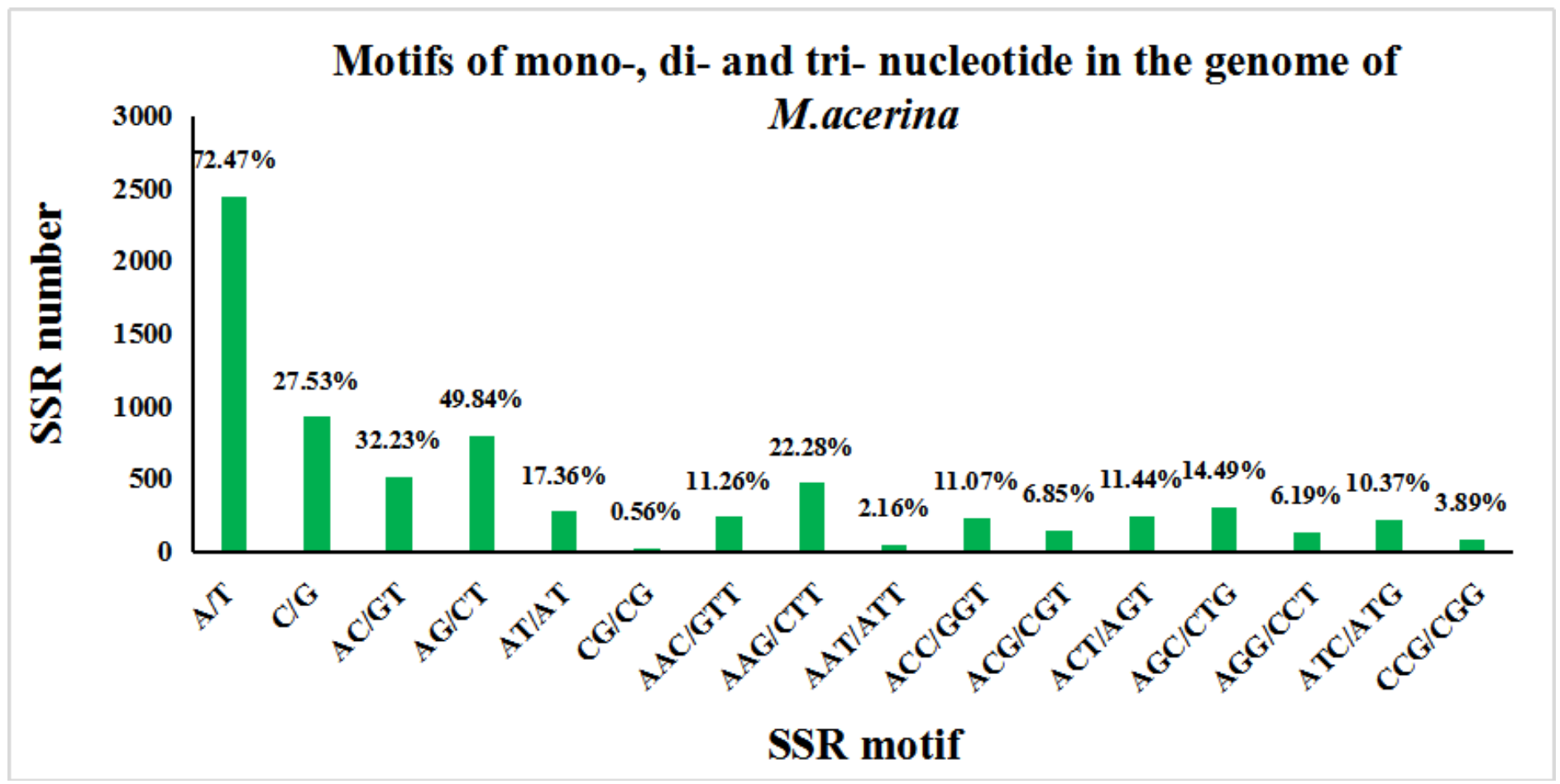

Figure 5

Motifs of mono-, di-, and tri-nucleotide simple sequence repeats (SSRs) in the whole genome of Mycocentrospora acerina. 


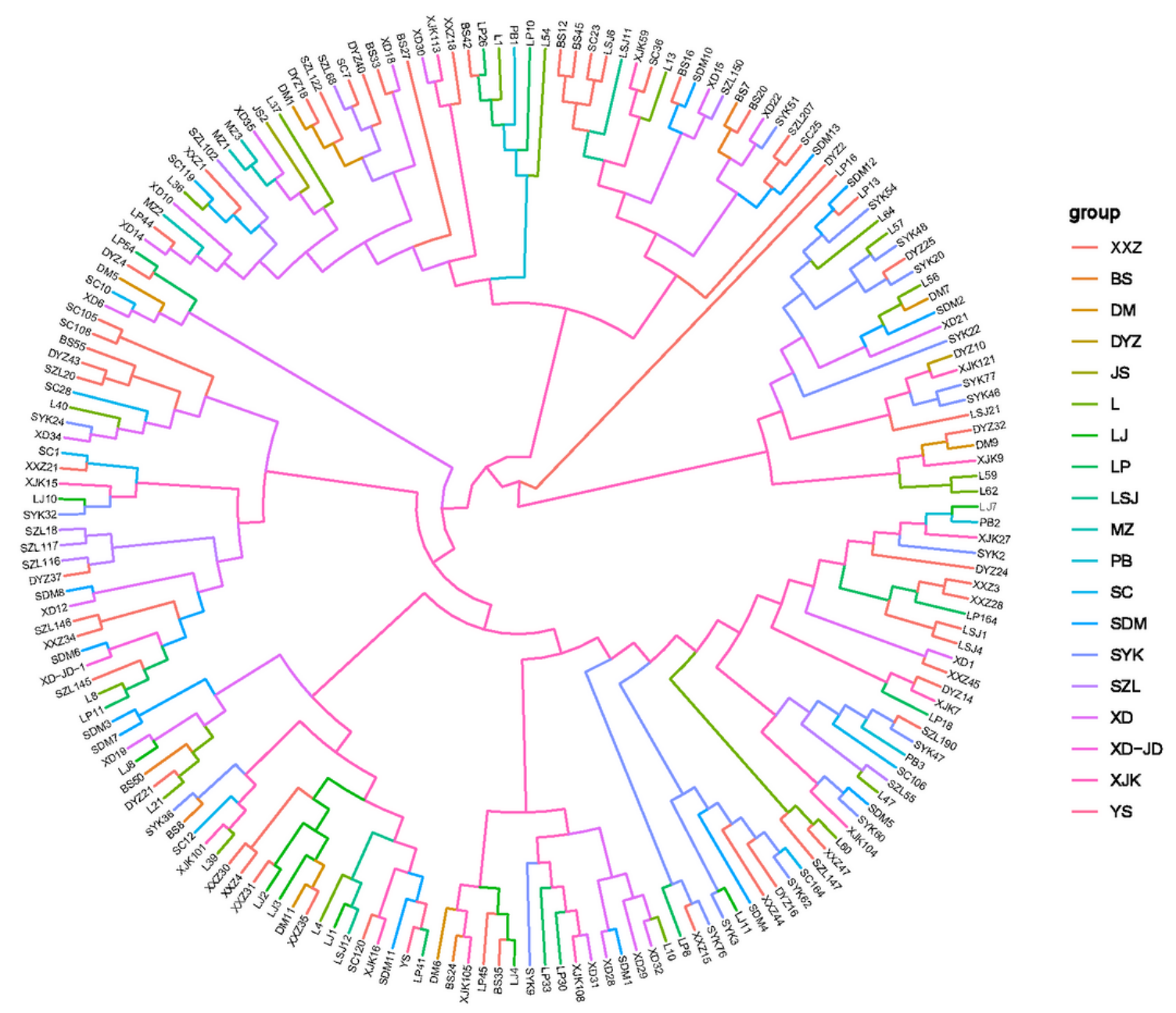

Figure 6

Cluster analysis of 187 Mycocentrospora acerina strains in Yunnan province based on genetic similarity coefficient. Different color meas different sampling location, SZL(Jianshui), BS(Luxi), JS(Jianshui), MZ(Mengzi), LP (Longpeng) and SC(Shaochong) were the isolates from Honghe, YS(Yanshan), WS(Wenshan), LSJ(Qiubei), SDM(Qiubei), XXZ(Qiubei), DM(Dumeng) and PB(Wenshan) were the fungis from Wenshan, DYZ and SYK were the isolates from Qujing, XD(Xundian), XD$J D$ (Xundian) and XJK(Shilin) were the fungis from Kunming, LJ prensents Lijiang.

\section{Supplementary Files}

This is a list of supplementary files associated with this preprint. Click to download.

- Supportinginformation.doc 